\title{
Communication
}

\section{Making Rice Production More Environmentally-Friendly}

\author{
Norman Uphoff ${ }^{1, *}$ and Frank B. Dazzo ${ }^{2}$ \\ 1 SRI International Network and Resources Center, International Programs, College of Agriculture and Life \\ Sciences, Cornell University, Ithaca, NY 14853, USA \\ 2 Department of Microbiology and Molecular Genetics, Michigan State University, East Lansing, MI 48824, \\ USA; dazzo@msu.edu \\ * Correspondence: ntu1@cornell.edu; Tel.: +1-607-255-1902
}

Academic Editors: Yu-Pin Lin, Dirk S. Schmeller, Wei-Cheng Lo and Wan-Yu Lien Received: 19 February 2016; Accepted: 16 April 2016; Published: 3 May 2016

\begin{abstract}
Irrigated rice production is one of the most essential agricultural activities for sustaining our global population, and at the same time, one of the agricultural sectors considered most eco-unfriendly. This is because it consumes a larger share of available freshwater resources, competing with varied ecosystems as well as other economic sectors; its paddy fields are responsible for significant emission of greenhouse gases; and the reliance on chemical fertilizers and various agrochemicals contributes to pollution of soils and water systems. These stresses on soils, hydrology and atmosphere are actually not necessary for rice production, which can be increased by modifying agronomic practices though more agroecologically-sound management practices. These, combined under the rubric of the System of Rice Intensification (SRI), can reduce requirements of irrigation water, chemical fertilizer and agrochemicals while increasing paddy yields and farmer's net incomes. Here we discuss how irrigated rice production can be made more eco-friendly for the benefit of farmers, consumers and the environment. This is achieved by introducing practices that improve the growth and functioning of rice plants' root systems and enhance the abundance, diversity and activity of beneficial soil organisms that live around plant roots and within the plants themselves as symbiotic endophytes.
\end{abstract}

Keywords: endophytes; microbiome; plant-microbe interaction; rhizobacteria; rhizosphere; rice; soil biota; System of Rice Intensification

\section{Introduction}

The world's respective needs for agricultural production to meet our population's food needs and for environmental protection - to ensure that our planet remains livable for both plants and animals, including ourselves-are often viewed as conflicting objectives. Indeed their relationship often gets framed in zero-sum terms, where achieving either objective must involve some sacrifice of the other. This is not a necessary opposition, however, as can be seen from the following discussion.

Irrigated, lowland rice cultivation, which covers about $56 \%$ of the total rice-cropped area, produces about $76 \%$ of the world's total rice crop. This staple food provides about $21 \%$ of humans' caloric energy and about $14 \%$ of their total dietary protein, even though rice is not a concentrated source of protein [1].

The irrigated production methods that generate three-fourths of our supply of rice are widely regarded as being eco-unfriendly, specifically in the following ways:

- These methods consume between a quarter and a third of the world's freshwater resources currently utilized, amounting to about half of the agriculture sector's annual irrigation use. 
- Over-extraction of groundwater for pumped irrigation to support rice and other production is lowering water tables, by $1-3 \mathrm{~m} \cdot \mathrm{yr}^{-1}$ in some parts of China and by up to $1 \mathrm{~m} \cdot \mathrm{yr}^{-1}$ in several parts of India [2].

- Use and overuse of inorganic $\mathrm{N}$ and $\mathrm{P}$ fertilizers for rice production contribute to soil and water contamination, as does the application of many agrochemical biocides to control rice crop pests and diseases.

- Irrigated rice paddy fields are a major source of anoxic methane $\left(\mathrm{CH}_{4}\right)$ emissions as well as other greenhouse gases (GHG) that are driving climate change and global warming [3,4].

These detriments, however, need not impinge upon the productivity and sustainability of our agroecosystems as much as they do at present. Why not? Because these negative effects can be significantly reduced by making certain simple, inexpensive, and indeed often cost-reducing changes in the standard agronomic practices for growing irrigated rice.

\section{The System of Rice Intensification}

These changes were first assembled some 30 years ago in Madagascar under the rubric of System of Rice Intensification (SRI) [5]. Although some of them are counterintuitive, SRI changes in the ways that rice plants, soil, water and nutrients are managed can elicit more productive and robust phenotypes from most rice varieties, while also conferring concomitant environmental benefits [6-9].

Because these changes raise crop yields at the same time that they lower production costs, farmer's net income ha ${ }^{-1}$ is raised by more than the improvement in yield. This increase, usually at least $25 \%-50 \%$ but often even more, is achieved with reduced consumption of water, as seen below, with more resilience to the effects of adverse climate, and with diminished greenhouse gas emissions. While this may sound too good to be true, the beneficial effects of such improvement in phenotypes by making changes in agronomic management have been demonstrated in $>50$ countries [10].

These effects do not depend on farmers purchasing and using new inputs. Instead they derive from making different and better use of available, nature-based resources. Farmers do not need to procure new or different seeds because the recommended practices of SRI improve the productivity of most rice varieties, both local (traditional) and improved (high-yielding and hybrid). It is true that the latter produce the highest yields with SRI management, but local varieties often command a higher market price because of consumer preferences, and they can become more profitable with agroecological management, given that SRI methods also lower farmers' costs of production.

Chemical fertilizers can be used with SRI alternative methods. But some of the best results are obtained just with enhancement of soil organic matter through the application of compost, mulch, or green manure [11]. This improves the structure, functioning and biological benefits of soil systems in ways that chemical fertilizer does not. SRI methodology was initially developed to benefit smallholders with very limited resources, and it is well-suited to their situation and needs. However, with mechanization, SRI can be extended to larger scales of operation [12]. Because the rice phenotypes that result from SRI management are more resistant to pests and diseases, the use of agrochemical biocides can be reduced or often even eliminated [9].

SRI management modifies standard practices for growing irrigated rice: transplanting very young and individual seedlings, reducing plant population density as well as the applications of water, seed and fertilizer. The resulting rice plants have larger, deeper, healthier, longer-lived root systems [13], while promoting the abundance, diversity and activity of beneficial soil organisms around plant roots (in the rhizosphere) and within the plants themselves [14]. These soil organisms of immense variety and uncountable numbers, ranging from microbes to earthworms, can be referred to simply as "the life in the soil" or more formally as the soil biota.

The size and health of living plant roots can be easily seen and evaluated if one carefully excavates, cleans and inspects them. Unfortunately this is seldom done as probably $95 \%$ of crop science investigations have focused on plants' above-ground organs and physiology. Roots thus remain a domain of flora incognita [15]. 


\section{Roles of Soil Biota}

The accompanying soil biota is considerably more difficult to grasp and appreciate than are plant roots. The mineral portion of the soil, which is what we see with our eyes, is only about half of the total volume of healthy soil, i.e., soil which is not compressed, compacted, virtually dead. In healthy soil, the air and water in pore spaces, virtually unseen, each constitute another $20 \%-25 \%$ of the soil's bulk volume. The diverse and dynamic living biomass in the soil, difficult to see and assess, comprises just a few percent of the soil's volume. However, its profound importance for crop productivity can be likened to 'the tail that wags the dog' $[16,17]$.

We are beginning to understand that the maintenance of human health and growth is heavily dependent on what is referred to as the human microbiome, comprised of the trillions of microorganisms that inhabit our bodies [18]. This diverse multitude of microorganisms provides myriad services and performs multiple functions to sustain our own healthy existence. Plants are similarly benefited and protected by what is called the soil-plant microbiome $[19,20]$. It will take several decades to unravel fully the complexity of its dynamics and interactions, but this is a promising "new frontier" for improving both agricultural production and environmental protection.

One of the remarkable things that we have already learned is that some soil microorganisms, collectively called endophytes, naturally reside within plant tissues in and around cells in the roots and above-ground plant organs. Recently we have been learning that microbial endophytes can influence, beneficially, the expression of plants' genetic potentials [21-24]. Further, we have evidence that certain microorganisms within the soil and plant tissues can stimulate the growth of plant roots. This creates positive feedback between the soil biota and the plants' root systems, enhancing the plants' health and productivity while reducing dependence on the application of chemical fertilizers to achieve higher crop yields. For example, inoculation of rice plant roots with certain rhizobacteria can increase the roots' number, length, absorptive surface area, and biovolume, as seen in Figure 1, and also significantly enhance their selective nutrient-uptake ability [24].
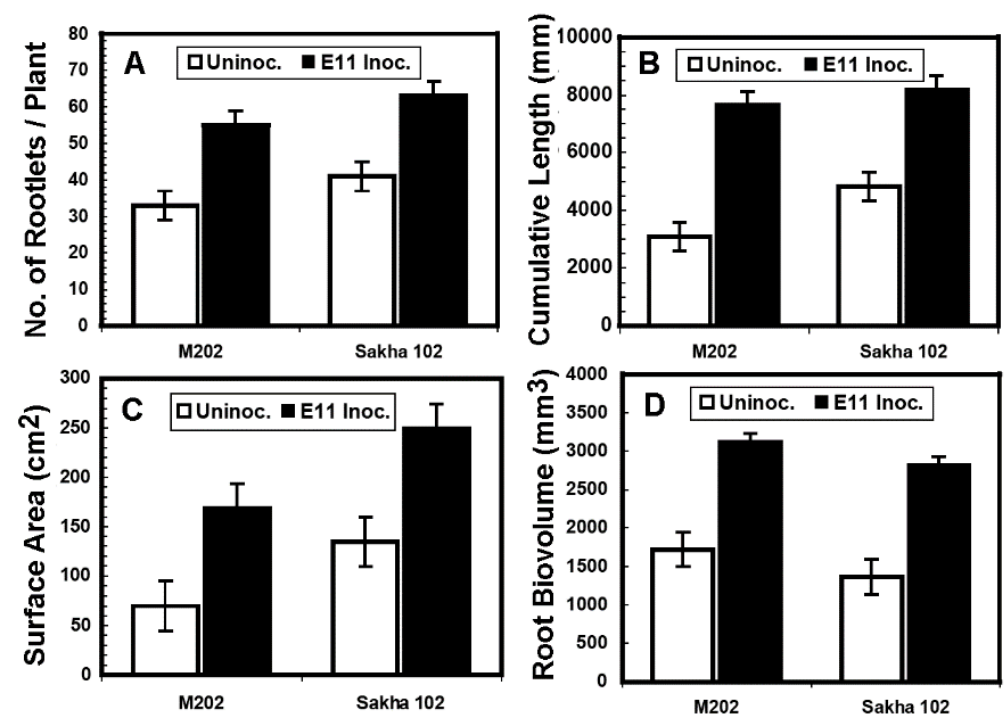

Figure 1. Effects of inoculation with Rhizobium leguminosarum bv. trifolii E11 on the root architecture of two rice varieties (M202 and Sakha 102): (a) rootlets per plant; (b) cumulative root length (mm); (c) surface area $\left(\mathrm{cm}^{2}\right)$; and (d) root biovolume $\left(\mathrm{mm}^{3}\right)$ [24]. Reproduced from Yanni et al. [24], with permission from CSIRO Publishing.

This makes sense from an evolutionary perspective because plant growth-promotive rhizobacteria and other organisms in the soil benefit from plants' growing larger, more vigorous root systems, and they can produce phytohormones that stimulate such growth [21,24,25]. More root growth supports 
greater photosynthesis in the leaves, which in turn increases roots' exudation of carbohydrates, amino acids, organic acids and other utilizable nutrients into the surrounding soil that benefit soil organisms. This establishes and maintains symbiotic dynamics both below-ground and within the plant [16,23].

\section{Resistance to Climatic Stresses}

The more productive phenotypes of rice that result from this plant-soil-microbial interaction have more resilience to climate stresses and greater water efficiency and productivity [9]. This is attributable to their having larger, deeper root systems that can access water at lower depths within the soil profile. More life in the soil also means that the soil itself has more porosity and can absorb and retain more water-and the biota itself contains more water - than if it is depleted of organisms at multiple scales. These benefits are largely due to microbial production of hygroscopic exopolysaccharides that strongly absorb water and promote soil aggregation. A number of studies have shown SRI-grown rice plants to be more resilient to drought and water stress, as well as more resistant to storm damage and cold temperatures, summarized in [9].

A meta-analysis of published studies from eight countries reporting SRI-conventional comparison trials listed in [26] has found that SRI rice crops, probably because of their expanded root systems, can produce higher grain yield while using 35\% less irrigation water per hectare, and $22 \%$ less total water ha $\mathrm{h}^{-1}$, i.e., irrigation plus rainfall. With increased yield, total water use efficiency (i.e., $\mathrm{kg}$ of rice produced per liter of water provided) averaged 52\% higher in the trials, and the water use efficiency of irrigation water was $78 \%$ greater [26].

The greater water productivity with SRI crop management was demonstrated across a wide range of ecozones, in both wet and dry seasons, for the full range of soil textures and $\mathrm{pH}$, and for rice varieties of short, medium and long duration [26]. A phenotypical difference in plant physiology that contributes to such results is that SRI plants produce more than twice as much carbohydrate photosynthates per unit of water transpired as do plants of the same variety grown conventionally [27].

\section{Reductions in Greenhouse Gas Emissions}

The fact that irrigated SRI plots have less net emission of greenhouse gases is a bonus, reducing the global warming potential contributed from irrigated rice paddies (in $\mathrm{CO}_{2}$ equivalence). It is expected that microbial-production of methane $\left(\mathrm{CH}_{4}\right)$ emissions will be reduced when paddies are no longer kept continuously flooded. But with SRI management that can reduce the need for synthetic fertilizer $\mathrm{N}$ applications, there are not offsetting increases in nitrous oxide $\left[\mathrm{N}_{2} \mathrm{O}\right]$ emissions, and sometimes there are even small reductions as the substrate for microbial production of $\mathrm{N}_{2} \mathrm{O}$ during denitrification is diminished [28-30]. An evaluation done in Andhra Pradesh state of India calculated that with SRI rice management, compared to current practices, GHG emissions were reduced by $40 \%$, groundwater extractions by $60 \%$, and fossil fuel consumption by $74 \%$ [31].

\section{Broader Implications}

These changes in age-old practices have been resisted, more by some scientists than by farmers, but there is now acceptance of SRI practices by major international development organizations like the World Bank, FAO, the International Fund for Agricultural Development, and UNEP [32-35]. The methods have also been adapted with similar results for rainfed (unirrigated) rice production [36,37], although not with the same reductions in magnitude of GHG emissions.

Further, with appropriate adjustments, SRI ideas and methods can be utilized to produce a variety of other important crops such as wheat, finger millet, sugarcane, some legumes and even some vegetables [38-40]. This experience with a variety of crops in addition to rice, across a wide range of countries, indicates that we can find ways to make the relationship between agricultural production and environmental conservation positive-sum. 


\section{Conclusions}

There are many current concerns about the sustainability of our development strategies, exacerbated by the impingements and perturbations of local, regional and global climate change. Much more needs to be done to rein in and reverse the drivers of climate change and to modify policies and incentives to modify current resource use out of consideration for the needs of future generations.

The agricultural changes suggested here are not a solution to all our current and impending constraints, but they can contribute to more positive economic and environmental dynamics, and with multiple benefits far outweighing any identifiable costs, there is no evident reason not to utilize them as part of a larger strategy to improve soil health and agricultural sustainability for generations to come.

Acknowledgments: This Communication summarizes and reports on the research and observations of others, whose work is acknowledged in the text and references. It was not funded by any grant of other funding.

Author Contributions: Norman Uphoff and Frank Dazzo have collaborated previously on this subject [23] and have been exchanging ideas and papers for over 10 years. Norman Uphoff prepared a first draft of this piece, and Frank Dazzo improved the presentation, particularly with regard to technical explanations and formulations, so that both could be satisfied with the presentation of ideas. Both have contributed to a number of the publications cited, combining social science and biological science perspectives.

Conflicts of Interest: The authors declare that they have no conflicts of interest as they did not develop the methodology of SRI reported on here or the biological processes that drive it. They are seeking to understand these effects and would like others to know about, evaluate, and where beneficial, utilize the opportunities identified.

\section{References}

1. IRRI. The Importance of Rice. Available online: http://www.knowledgebank.irri.org/ericeproduction/ Importance_of_Rice.htm (accessed on 19 February 2016).

2. Rodell, M.; Velicogna, I.; Famiglietti, J.S. Satellite-based estimates of groundwater depletion in India. Nature 2009, 466, 999-1002. [CrossRef] [PubMed]

3. Tuong, T.P.; Bouman, B.A.M. Rice production in water-scarce environments. In Water Productivity in Agriculture: Limits and Opportunities; Kijne, W., Barker, R., Molden, D., Eds.; CABI: Walllingford, UK, 2003; pp. 53-67.

4. Bouman, B.A.M.; Barker, R.; Humphreys, E.; Tuong, T.P.; Atlin, G.; Bennett, J.; Dawe, D.; Dittert, K.; Dobermann, A.; Facon, T.; et al. Rice: Feeding the billions. In Water for Food, Water for Life; International Water Management Institute: Colombo, Sri Lanka, 2007; pp. 515-549.

5. Laulanié, H. Le système de riziculture intensive malgache. Tropicultura 1993, 11, 110-114.

6. SRI-Rice. Available online: http://sri.cals.cornell.edu (accessed on 19 February 2016).

7. Uphoff, N. Supporting food security in the 21st century through resource-conserving increases in food production. Agric. \& Food Secur. 2012, 12. [CrossRef]

8. Thakur, A.K.; Uphoff, N.; Stoop, W.A. The scientific underpinning of the System of Rice Intensification: What is known so far? Adv. Agron. 2016, 135, 147-179.

9. Uphoff, N. Developments in the System of Rice Intensification (SRI). In Achieving Sustainable Rice Cultivation; Sasaki, T., Ed.; Burleigh-Dodds: Oxford, UK, 2016.

10. SRI-Rice. SRI Information by Country. Available online: http://sri.cals.cornell.edu/countries/ (accessed on 19 February 2016).

11. Uphoff, N.; Randriamiharisoa, R. Reducing water use in irrigated rice production with the Madagascar System of Rice Intensification. In Water-Wise Rice Production; Bouman, B.A.M., Hengsdijk, H., Hardy, B., Bindraban, P.S., Tuong, T.P., Ladha, J.K., Eds.; International Rice Research Institute: Los Baños, Philippines, 2002; pp. 71-88.

12. Sharif, A. Technical adaptations for mechanized SRI production to achieve water saving and increased profitability in Punjab, Pakistan. Paddy Water Environ. 2011, 9, 111-119. [CrossRef]

13. Barison, J.; Uphoff, N. Rice yield and its relation to root growth and nutrient-use efficiency under SRI and conventional cultivation: An evaluation in Madagascar. Paddy Water Environ. 2011, 9, 65-78. [CrossRef]

14. Anas, I.; Rupela, O.P.; Thiyagarajan, T.M.; Uphoff, N. A review of studies on SRI effects on beneficial organisms in rice soil rhizospheres. Paddy Water Environ. 2011, 9, 53-64. [CrossRef] 
15. Eschel, A.; Beeckman, T. Plant. Roots: The Hidden Half, 4th ed.; CRC Press: Boca Raton, FL, USA, 2013.

16. Pinton, R.; Varanini, Z.; Nannapieri, P. The Rhizosphere: Biochemical and Organic Substances at the Plant. Soil Interface; CRC Press: Boca Raton, FL, USA, 2007.

17. Uphoff, N.; Ball, A.S.; Fernandes, E.; Herren, H.; Husson, O.; Laing, M.; Palm, C.; Pretty, J.; Sanchez, P.; Sanginga, N.; et al. Biological Approaches to Sustainable Soil Systems; CRC Press: Boca Raton, FL, USA, 2006.

18. Cho, I.; Blaser, M.J. The human microbiome: At the interface of health and disease. Nat. Rev. Genet. 2012, 13, 260-270. [CrossRef] [PubMed]

19. Turner, T.R.; James, E.K.; Poole, P.S. The plant microbiome. Genom. Biol. 2013, 14. [CrossRef] [PubMed]

20. Mendes, R.; Garbeva, P.; Raajmakers, J.M. The rhizosphere microbiome: Significance of plant beneficial, plant pathogenic and human pathogenic microorganisms. FEMS Microbiol. Rev. 2013, 37, 634-663. [CrossRef] [PubMed]

21. Chi, F.; Shen, S.H.; Cheng, H.P.; Jing, Y.X.; Yanni, Y.G.; Dazzo, F.B. Ascending migration of endophytic rhizobia, from roots to leaves, inside rice plants and assessment of benefits to rice growth physiology. Appl. Environ. Microbiol. 2005, 71, 7271-7278. [CrossRef] [PubMed]

22. Chi, F.; Yang, P.F.; Han, F.; Jing, Y.X.; Shen, S.H. Proteomic analysis of rice seedlings infected by Sinorhizobium meliloti 1021. Proteomics 2010, 10, 1861-1874. [CrossRef] [PubMed]

23. Uphoff, N.; Chi, F.; Dazzo, F.B.; Rodriguez, R.J. Soil fertility as a contingent rather than inherent characteristic: Considering the contributions of crop-symbiotic soil microbiota. In Principles of Sustainable Soil Management in Agroecosystems; Lal, R., Stewart, B., Eds.; CRC Press: Boca Raton, FL, USA, 2013; pp. 141-166.

24. Yanni, Y.G.; Rizk, R.Y.; EL-Fattah, F.K.; Squartini, A.; Corich, V.; Giacomini, A.; de Bruijn, F.; Rademaker, J.; Maya-Flores, J.; Ostrom, P.; et al. The beneficial plant growth-promoting association of Rhizobium leguminosarum bv. trifolii with rice roots. Aust. J. Plant Physiol. 2001, 28, 845-870.

25. Hardoim, P.R.; van Overbeek, L.S.; Berg, G.; Pirttilä, A.M.; Compant, S.; Campisano, A.; Döring, M.; Sessitsch, A. The hidden world within plants: Ecological and evolutionary considerations for defining functioning of microbial endophytes. Microbiol. Mol. Biol. Rev. 2015, 79, 293-320. [CrossRef] [PubMed]

26. Jagannath, P.; Pullabhotla, P.; Uphoff, N. Meta-analysis evaluating water use, water saving, and water productivity in irrigated production of rice with SRI vs. standard management methods. Taiwan Water Conserv. 2013, 61, 14-49.

27. Thakur, A.K.; Uphoff, N.; Antony, E. An assessment of physiological effects of System of Rice Intensification (SRI) practices compared to recommended rice cultivation practices in India. Exp. Agric. 2010, 46, 77-98. [CrossRef]

28. Choi, J.D.; Kim, G.; Park, W.; Shin, M.; Choi, Y.; Lee, S.; Kim, S.; Yun, D. Effect of SRI water management on water quality and greenhouse gas emissions in Korea. Irrig. Drain. 2014, 63, 263-270. [CrossRef]

29. Gathorne-Hardy, A.; Reddy, D.N.; Venkatanarayana, M.; Harriss-White, B. A Life Cycle Assessment (LCA) of greenhouse gas emissions from SRI and flooded rice production in SE India. Taiwan Water Conserv. 2013, 61, 110-125.

30. Dill, J.; Deichert, G.; Le, T.N.T. Promoting the System of Rice Intensification: Lessons Learned from Trà. Vinh. Province, Vietnam; German Agency for International Cooperation (GIZ) and International Fund for Agricultural Development: Hanoi, Vietnam, 2013.

31. Gathorne-Hardy, A.; Reddy, D.N.; Venkatanarayana, M.; Harriss-White, B. System of Rice Intensification provides environmental and economic gains but at the expense of social sustainability: A multi-disciplinary analysis in India. Agric. Syst. 2016, 143, 159-168. [CrossRef]

32. World Bank Institute. Available online: http://info.worldbank.org/etools/docs/library/245848/ (accessed on 19 February 2016).

33. UN Food and Agriculture Organization (FAO). Save and Grow: Maize, Rice and Wheat-A Guide to Sustainable Crop. Production; Chapter 3; FAO: Rome, Italy, 2016.

34. International Fund for Agricultural Development. Available online: http://www.ifad.org/english/sri/ (accessed on 19 February 2016).

35. TEEB. Agriculture and Food: An Interim Report; The economics of ecosystems and biodiversity program, U.N. environmental program; TEEB: Geneva, Switzerland, 2015.

36. Kabir, H.; Uphoff, N. Results of disseminating the System of Rice Intensification (SRI) with farmer field school methods in northern Myanmar. Exp. Agric. 2007, 43, 463-476. [CrossRef] 
37. Sinha, S.K.; Talati, J. The impact of system of rice intensification (SRI) on paddy productivity: Results of a study in Purulia District, West Bengal, India. Agric. Water Manag. 2007, 87, 55-60. [CrossRef]

38. Behera, D.; Behera, D.; Chaudhary, A.K.; Vutukuru, V.K.; Gupta, A.; Machiraju, S.; Shah, P. Enhancing Agricultural Livelihoods through Community Institutions in Bihar, India; World Bank: New Delhi, India, 2013.

39. Abraham, B.; Araya, H.; Berhe, T.; Edwards, S.; Gujja, B.; Khadka, R.B.; Koma, Y.S.; Sen, D.; Sharif, A.; Styger, E.; et al. The System of Crop Intensification (SCI): Reports from the field on improving agricultural production, food security, and resilience to climate change for multiple crops. Agric. E Food Secur. 2014, 2. [CrossRef]

40. Dhar, S.; Barah, B.C.; Vyas, A.K.; Uphoff, N. Evaluation of System of Wheat Intensification (SWI) practices as compared to other methods of improved wheat cultivation in the north-western plain zone of India. Arch. Agron. Soil Sci. 2015, 10. [CrossRef]

(C) 2016 by the authors; licensee MDPI, Basel, Switzerland. This article is an open access article distributed under the terms and conditions of the Creative Commons Attribution (CC-BY) license (http://creativecommons.org/licenses/by/4.0/). 